\title{
CORRESPONDENCE
}

\section{SARTRE'S ONTOLOGY}

\begin{abstract}
7 HE editors are happy to publish the following extracts from letters 1 exchanged between John Yolton of York University and Albert Shalom of McMaster University induced by publication in this journal last March of an article by Shalom on Sartre's Ontology.
\end{abstract}

7. 1 . April $7 / 67$.

I have just finished reading your interesting article on " $\mathrm{L}$ 'Ontologie de Sartre." It seems to me to be an illuminatingly close reading of Sartre, the kind of discussion of this type of philosophy one does not usually find. Your discussion is clear, crisp, and very helpful.

I think you are correct in your conclusion but I would like to think there might be a qualification. I am not at all sure it can be made, however. I frequently think I come close to seeing what Sartre is trying to say about "transphénomenalité." The contradiction you suggest on p. $55^{\mathrm{I}}$ is very likely inescapable but it just may capture a truth! The problem is, can one who defines being in terms of awareness to an experiencer talk about the being of the phenomena; does it make sense to have both "en-soi" and "pour-soi?" If we take the complex "phénomène-fonction-de-conscience," can we assert that that complex exists? We seem to have said there are phenomena and there is awareness. Only in the sense of being for awareness? I think perhaps not, since if there are phenomena and awareness, they are as well as being for self. I am very close to nonsense but perhaps not all the way. The problem may be that, for the phenomenalist self, no assertion of the being of appearances other than the being for self can be asserted or conceived. But it may be possible for the philosophic self to understand -even to say in the ways in which Sartre tries to say-the nonphenomenality of that complex.

You say on p. 554 that this talk of "le "transphénomène" " is only a dogmatic personal conviction. I am not sure I see all that you put into this charge. If you mean Sartre the phenomenalist cannot say it, I think

1 "Remarques sur l'Ontologie de Sartre" par Albert Shalom. DialogueRev. Can. de Phil., Vol. 5, No. 4 (1967), pp. 54 I-554. 
you are right. But perhaps Sartre the philosopher can. There is another problem, though. "Néant" is just the fact of being outside being for a self, but the fact that for Sartre "néant" can be experienced in "l'ennui" and "la nausée" indicates that it is not just there (though it may be there for no reason, or no discernible reason), that even $i t$ is for a subject. What I have attempted to call "the philosophic self" is my intellectual way of attempting to do what Sartre tries to capture experientially in certain non-intellectual states. He would secm to say one can experience the trans-phenomenal character of being whereas I only want to suggest we can perhaps think it. I do not understand why you bring in the notion of this aspect of the sense of the world being constitutive of things. But do you think there is any hope of success for this enterprise, put in my way?

F. $r$.

A. S., April r3/67.

If I understand you correctly, what you are saying is:

a) that there is a complex called "phénomène-fonction-de-conscience;"

b) that since that complex is a fact, it in some sense is more than a phenomenon; and that to that extent Sartre is right. (This is how I understand your sentence: "We seem to have said there are phenomena and there is awareness. Only in the sense of being for awareness? I think not, since if there are phenomena and awareness, they are as well as being for self.")

I think two things must be clearly distinguished here: firstly, the actual problem we are faced with in "perceiving (and knowing) an object;" secondly, Sartre's solution to this problem. What I'm saying is that Sartre's solution is, in my opinion, not merely false, but dangerously false because it depends entirely upon a deliberate confusion of terminology (when I say "deliberate" I don't mean that he was intellectually dishonest-though he infuriates me so much that I'm sometimes tempted to think so-but that he was probably so carried away by the internal conceptual logic of his own system that he succeeded in pulling the wool over his own eyes).

As regards the first point, all I need say is that I think it is misleading to approach the problem in terms of "phenomena" ("sense-data," "sense-impressions"). For me, the "phenomenon" is the basic problem, an ambiguous term, and not in any sense a given. From this it follows 
that point $a$, above, itself needs analysis. To that extent, I think you would agree with me. But where we seem to part ways is that you hold, if I understand you correctly, that point $b$ gives, if not a solution, at least the direction of a possible solution. This, I do not agree with at all. For me, point $a$ means, in fact, to accept point $a$, and then to try and find a way out. But $I$ hold that the error lies in accepting point $a$ at its face value, and then trying to interpret it.

As regards the second point (Sartre's solution) let me try to make the argument clearer. The basic problem is the status of this so-called "transphenomenon." Since I hold that the "phenomenon" is a bogus entity, I was naturally very keen on discovering how Sartre dealt with it. One possible solution is that of Kant: like Sartre, he also accepts Hume's disastrous starting-point. And being, unlike Sartre, a really great philosopher, his Critique of Pure Reason is, to my mind, the most heroic attempt at solving a misleadingly stated problem. But rejecting this solution, Sartre proposes his own which is summarised in the notion of the "transphenomenality of phenomena." Let me here quote a phrase from your letter. You say that "Néant is just the fact of being outside being for a self." But don't you find it strange that the word "nothingness" should be used to qualify the word "being," in whatever way this latter word is interpreted? Clearly, the word "nothingness" is not to be understood in the (literal) sense of "total absence of anything whatsoever." But then how must it be understood? It could simply mean "nothing which I can specify." But then all Sartre would be saying is: "I don't know what there is apart from phenomena." But he is obviously not saying this at all. What he is saying is that phenomena, like their mirroring creator, the self, are simply a fact which have no "raison d'être." They are "de trop," superfluous for all eternity. And this, in my opinion, gives the clue to his so-called solution.

It is here that I think one must bring in the category-mistake or type-mistake in Sartre's argument: i.e., his transformation of a belief, a personal conviction, into an actual constitutive element of existence. By qualifying both phenomena and the consciousness of which they are the object as "sans raison d'être," "de trop" etc., he is saying that this pipe in front of me is:

a) a series of sense-impressions ("phenomena").

b) a gratuitous fact.

But what distinguishes $b$ from $a$ is not the notion of "a fact," but the notion of "gratuitousness." If $b$ were to read: "a fact," all that that 
would mean, for Sartre, is: "it is a fact that this pipe is a series of impressions." The philosophy of logic is not his domain, in any sense, and he would make nothing of the problem: "what is a fact?". Hence I hold that for him what is clearly important is the notion of gratuitousness ("sans raison d'être" etc.). It is certainly the literary appeal on which his reputation is based.

Therefore, what he is actually doing is predicating of this pipe in front of me both "phenomenality" (brown, curved ... etc.) and "gratuitousness" ("de trop" etc.). He is saying that existence is phenomenal and gratuitous. And he is adding that we experience this gratuitousness of existence in those "privileged" moments called "nausée." What I'm saying is that this argument is simply absurd. We cannot predicate "gratuitousness" of a pipe or of anything else in the so-called "phenomenal world," since gratuitousness is a value-word and not a descriptive-word. We can, of course, assert that existence is pointless or gratuitous or absurd or whatever; but this is a very different thing, surely? It is a matter of giving one's own views regarding the "meaning" (or absence of meaning) of the universe. Again, I do not believe that we can experience "gratuitousness," since it isn't the kind of thing which can be a possible object of experience. Hence this "nausea," which is supposed to be the sign or symbol of "gratuitousness," "absurdity" etc., is simply a word signifying Sartre's a priori value-judgment. But Sartre's argument is essentially to do just that: to transform a value-judgement into a constitutive element of existence. Hence my conclusion that the whole argument leading to the assertion of the "transphenomenality of phenomena" (which I understand as meaning "the gratuitous fact of there being phenomena") is a totally spurious argument based on a complete confusion of philosophical terminology.

Your own position, if I understand you correctly, would be along the lines of leaving out the question of "gratuitousness" and stressing the notion of a "phenomenal world" as a fact. That, at any rate, is what I understand by your sentence: "The problem may be that for the phenomenalist self no assertion of the being of appearances other than the being for self can be asserted or conceived. But it may be possible for the philosophic self to understand-even to say in the ways in which Sartre tries to say-the non-phenomenality of that complex." All that I can say here is: a) that I believe that you will run into difficulties regarding the notion (implicit or expressed) of the so-called "phenomenal" world as a fact; b) that if a "phenomenon" is, as I believe, a concept very badly in need of breaking down, then it follows that the whole approach is pointless. 
I should like to have your reaction to this attempted clarification. I enclose a paper where a somewhat different approach is attempted. ${ }^{2}$

A. S.

7. Y., April 19/67.

I enclose an old article of mine which may be of interest. ${ }^{3}$ It still seems sound to me though I think I would put some of the points differently now.

I have read your article in Les Études Philosophiques with much interest. But it may surprise you to have me say that you seem to me to present Sartre's ontology precisely and clearly in that article. I do not refer to pp. 474-477, where you are discussing Sartre, but rather to pp. 489-497 where you are offering your own analysis of "existence." The problem as you state it on pp. 490-49 I seems to be just how Sartre conceived of the problem. The following sentence on p. 492 puts the problem clearly: "Et de cela il s'ensuit que les termes descriptifs 'feuille' et 'verte' dépendent du type particulier de ma subjectivité comme être humain. Mais alors, qu'en est-il de l'objet que je suis en train de voir comme une 'feuille verte' et que mon hypothétique créature est en train de 'voir' ou d'expérimenter d'une manière différente? Cet objet, qu'estil 'réellement'?" Or take the sentence on p. 495: "Et ce qui constitue le paradoxe c'est que l'existence n'est pas séparable de ce-qui-existe." Isn't this just like saying the "en-soi" cannot be separated from the "pour-soi?" And when you talk of the contingency of the universe, how does this differ from Sartre's talk of gratuitousness? (p. 497)

One clear difference between what I see you saying in this article and Sartre is that Sartre wants to say we can experience the world "ensoi," "l'objet en tant qu'existant," as you put it in the "Exister" article. I rather think you are right in saying no characterization can be given to the existing object in this sense which is not fetched from our experience and language, the language of experience is our language of existence, save that we have to make the distinction in that language between the object as known and the object as it is as an existent.

These rough thoughts will receive a careful clarification in a few weeks time. In the meantime, you might see whether you think I am

2 "Exister" par Albert Shalom. Les Études Philosophiques, no. 4, 1966, pp. 47 I497.

3 "The Metaphysics of En-Soi and Pour-Soi" by John Yolton, The Journal of Philosophy, Vol. 48, 1951, pp. 548-556. 
right in saying your "Exister" article puts the problem of my letter and of Sartre's ontology and also offers a solution which is very close to that offered by Sartre. Perhaps what I need is an indication from you as to where your solution does depart from Sartre's. I shall look forward to more discussion with you on this problem.

F. $r$.

7. ., April $29 / 67$.

In my letter of April I 9 , I said that your "Exister" article put Sartre's metaphysics precisely and clearly, including the paradox. I now see that this claim is not quite correct. What it is correct to say is, I think, that your analysis of existence is very close to that of Sartre's, the paradox in your analysis finds its parallel in Sartre. You want to say that all talk and thought of existing things can only be done in terms of the language of experience, that we can say nothing about an object as an existent, save to say that it exists. Moreover, even to say that much requires me to know what the object is that I have said exists: I have to think of its properties, I must in part at least characterize it. To say what an object is is to cite some features of the object known by us. To say that that object exists just reminds us that its existence does not depend upon our knowledge or our experience. The existence of the object is independent of us ontologically but the properties by means of which we know and characterize it arise in experience.

We might distinguish between two sorts of phenomenalism. (I) A phenomenalism of meaning or cognition would say that what is meant by an object can only be stated in terms found in experience. (2) A phenomenalism of existence would say that to be is to be perceived. As I understand your own analysis, you accept the first sort of phenomenalism but reject the second as a confusion. The first sort still leaves it open for you to speak of the existence of the objects known. What I tried to do for Sartre was to suggest a way in which he could do for his phenomena-which depend for their existence upon the subject-what you did for objects. If a phenomenalist of the second sort wants to call attention to a fact about his world, namely, the fact that it and its features (properties, ordered groups of properties, self, awareness, etc.) exist, he does not want to say they exist independent of his awareness, since that is just what he rejects. But existing for awareness is a species of existing, nevertheless. One remark Sartre makes about his existent is that it is gratuitous, has no reason, etc. I do not see this feature of his existent as a constitutive element of existence, as you do. Nor can I see where there is a category-mistake, unless you want to 
say such a mistake is made whenever someone offers a metaphysics. I take Sartre to be presenting us with a metaphysical view. Of course, he thinks that view is true, I suppose: he thinks it is the case that "ensoi" is not and cannot be separated from "pour-soi," thinks it is the case that what there is is "de trop," etc. I suspect you think we can determine which metaphysical view is correct, between competing ones. I am far from clear in seeing how we would go about that task. Hence, I may be more sympathetic to any metaphysical position than you are. What I was raising in my first letter was the possibility of a phenomenalist of the second sort drawing the distinction between objects as known and objects as existing.

You seem to get stuck before reaching this point, in dealing with Sartre. As you say in your letter, the concept of "phenomena" bothers you. From the fact that that concept needs analysis, needs as you say "breaking down," you conclude that the "whole approach is pointless." I would only conclude that the concept needs analysis. The analysis may lead to the conclusion that the concept has to be given up, but I do not sec why. I think "phenomena" for you means "sense-data." I do not see that one needs to mean by "phenomena," "sense-data". The phenomenalism of meaning deals with phenomena: objects as known are phenomena. Phenomena in the full sense may have to be dependent upon subjects, upon awareness, but even then it is not clear to me that the phenomena have to be bundles of sense-data. But even if this sort of phenomenalism does in the end lead to groups of qualities, why does that particular analysis have to be rejected as pointless? I suspect your answer is, because it is false. As I say, I do not want to get involved in deciding which metaphysics is true or false. Can't a false metaphysic have problems inherent in it which can be solved?

If you are prepared to accept my characterization of your analysis in "Exister" as a phenomenalism of meaning or of cognition, how does your analysis of objects as known differ from that of Berkeley or Hume? What can you say about objects other than the qualities they disclose in your experience? This pen is green, long, hard, etc.? Are you saved from phenomenalism only by your assertion that the pen exists independent of you? That is an assertion, is it not, and not a predication? To assert that the world is gratuitous is not to describe it, if to describe means to list sensible predicates. By the same token, to say objects exist, in your sense of "exist," is not to cite a predicate; it is to make a claim about objects, to reveal a personal conviction. Or do you want to say that we experience the existence of objects? The second to last paragraph in your "Exister" article says we must accept the universe before 
we can understand it. As I said in my last letter, I do not see how the contingency you there talk about differs from Sartre's gratuitousness, nor am I clear how this acceptance differs from Sartre's attempt to experience the transphenomenality of his world. As I said at the beginning of this letter, your metaphysical position is not the same as Sartre's, but it is very close to it and parallels it in many ways.

I would be most interested to learn where you think I am wrong in interpreting your analysis of existence. For if $I$ am right in suggesting that yours is a brand of phenomenalism, I may have indicated part of an answer to your last question in your letter: what I mean by "phenomena" in the two phenomenalisms I distinguish here. My answer to your query about "néant" is, I hope, found in the old article I sent you. I also wonder whether "le néant" may not play another role for Sartre. Can it not be a term applied to the totality as a totality, nothingness being the reference to the world outside awareness, nothingness "pour. soi ?" A wild thought!

7. $r$.

A. S., May $2 / 67$.

Thank you very much for your paper and your letters. Your paper certainly represents a positive interpretation of L'Etre et le Néant, but it is one with which I clearly do not agree-at least as regards the very basic point of "nothingness." This, I think, is the major point of our differences. According to your interpretation, "le néant" is essentially an element which we bring into the world; according to my interpretation there is more to it than that. In the first place, I'm struck by the fact that, in your paper, even as regards the "pour-soi," you nowhere state that the "pour-soi" is, for Sartre, in some sense basically a "néant." You say "Liberty is the defining characteristic of man." But what is the basis of man's liberty? You yourself say that, for Sartre, "man's freedom follows from his very nature" (554). I agree, but then what is his nature? To this, your answer is: "Man cannot help but be free since being free means being what he is, the 'pour-soi' ...". But surely this is not meant to be an explanation since as such it would clearly be circular: "the 'pour-soi' is free because of its nature which is precisely to be a free 'pour-soi' ...". It seems to me that Sartre bases his view of freedom on the borrowed concept of man as essentially a "pro-ject," a "dépassement perpétuel." Hence the notion of the self as "être en soi manqué." The self is by nature an absence, a no-thingness, because it is a permanent pro-ject, a permanent forward movement. This curiously simplifying view of the self is clearly brought out in the 
Transcendence of the Ego. In this sense of "nothingness," then, "nothingness" is at the heart of the "pour-soi." Freedom is the consciousness that because of this, we necessarily have in our hands the making of our own existence.

You then say that "Sartre does not ask us to believe in nothingness as an ingredient in the 'en-soi,' detached from the 'pour-soi' of the observer" (552). I hold, on the other hand, that because Sartre, adopting the phenomenological procedure, gives absolutely no clear analysis of the distinction between existence and consciousness, simply substantialises them under the loaded terms of "en-soi" and "pour-soi," so he constantly plays on two levels: on the one, making existence (misleadingly understood as "en-soi") basic, and interpreting consciousness as a sort of parasite on existence; on the other, making consciousness (equally misleadingly understood as "pour-soi") basic, and interpreting existence (this time differently understood as the world of appearances) as something brought about by consciousness. I believe that the various passages I quoted support this view of his playing on two levels, e.g. "c'est par la réalité humaine qu'il y a un monde"4 and "il n'y a, en dehors de l'en-soi, rien sinon un reflet de ce rien."

The problem is to find out whether or not Sartre does, in fact, hold "le néant" to be at the basis of the whole of existence. You certainly agree that he holds that the totality of existence, both "en-soi" and "pour-soi," is "for nothing," "gratuitous" and so on. But you also say that I'm wrong in holding that, for Sartre, "gratuitousness" as the sense of the world becomes a constitutive element of his concept of existence, and that as a result he perpetrates a category-mistake. And yet it seems to me that the last comment in your letter tends towards a view which is not entirely different to my view. You suggest that there may be a second sense of the word "nothingness" apart from what the subject brings in when he is aware of absence: "Can it not be a term applied to the totality as a totality, nothingness being the reference to the world outside awareness ...". You say that this is probably a "wild thought," but I don't think it is quite so wild, though I interpret it differently from what your sentence implies.

Sartre's first step is to agree with Hume: the "objective" world must be viewed, to begin with, as a series of sense-impressions. His next step is to assert that this is not enough: there is something else which he calls the "transphenomenality of phenomena." And a further piece of infor-

4 J.-P. Sartre, L'Etre et le Néant (Paris: Gallimard, 1943), p. $3^{69 .}$

5 Ibid., p. 225. 
mation is that Kant's solution is not satisfying: there is no "noumenon" lying behind the world of sense-impressions. What, then, are we left with? Phenomenal reality as a series of sense-impressions and phenomenal reality as something more than a series of sense-impressions. What is this something "more?" It isn't a "noumenon," says Sartre, but something which characterises the phenomena themselves.

Turning now for a moment to the "en-soi," what characterises it is that it is simply "there," fully "there." It hasn't the kind of "nothingness" which characterises the "pour-soi" as a perpetual, temporal, project. But what docs being simply "there" mean? We know that whatever is simply "there" is also, or can also be, a series of sense-impressions. And we also know that there isn't a noumenal world, a world "in itself," radically independent of consciousness. To avoid a reduction to senseimpressions (and hence to subjectivity), and to avoid the notion of a noumenon lying "behind" sense-impressions, Sartre posits the notion of "the being of phenomena." He tells us that this "being of phenomena" is:

a) co-extensive with the phenomena,

b) escapes the "phenomenal condition" of the phenomena (I6);

and what he means by the second notion is that the "being of phenomena" is itself "en-soi" (29), i.e. simply "there," fully "there." It is clear, then, that when Sartre holds that the world of appearances is both a series of sense-impressions and more than this, what the "more" means is that these sense-impressions are simply "there." Of course, one mustn't now say "sense-impressions" since it would be perfectly absurd to say that these subjectively grounded phenomena are simply "there": what we must say is that the phenomenal world, the world of appearances, of chairs, tables etc. has this characteristic of being simply "there." This simply illustrates, in my opinion, the kind of playing on two levels which is so characteristic of this work. (I'm not, of course, concerned with the, to me, uninteresting question of whether Sartre was clearly aware of what he was saying. Personally, I tend to doubt this: the book is anything but a clearly thought out work, and its best parts are not the socalled "philosophical" parts, but the more literary parts. What I'm trying to get at is the internal conceptual logic of a piece of writing). So, then, the upshot is that what we are faced with is the question of what it means to say that the world of appearances is:

a) a series of sense-impressions,

b) simply "there." 
Now Sartre has a curious phrase to the effect that "before consciousness one can only conceive of a fulness of being" (22). Leaving aside conceptual hole-picking regarding the phrase "before consciousness one can ... conceive," part of what the sentence aims at saying is clear enough and, I believe, perfectly true: that a world was "there" before man (the Dasein, the "human reality" . . etc.) appeared on the scene.

So, then, the world is simply "there," sense-impressions are simply "there," and, ultimately, we are told that consciousness as well is simply "there." But now observe the language in which this notion is expressed. The "pour-soi," says Sartre, "is conscious of its own "facticite," (i.e. of its being there as a fact), and it "has the feeling (le sentiment) of its total gratuitousness, it grasps itself as being there (étant là) for nothing (pour rien), as being superfluous (de trop)" (126). Again, being-in-itself is "the presence of its absolute contingency," it is "an irreducibility of indifference" (son irréductibilité d'indifférence). And the quotations could be multiplied.

It seems to me that all these texts are saying essentially the same thing: namely, that being simply "there" means, is synonymous with, being "superfluous," "gratuitous." To say "simply there" is to say "superfluous" or "gratuitous." The terms are interchangeable: wherever you read "there," you can read "superfluous" or "gratuitous."

But if now we return to this so-called "being of appearances" or (which comes to the same thing) the "transphenomenality of phenomena," all we have to do is to substitute the terms which Sartre himself clearly regards as substitutable. We are told that the world of appearances is:

a) a series of sense-impressions,

b) an "en-soi," i.e. simply "there."

And we are also told, without any attempt at relating the assertion to the previous statement, that independently of the "pour-soi" the world must also be considered as "en-soi," i.e. as being simply "there." But we now know that to be simply "there" is the same thing as to be superfluous or gratuitous. And it therefore follows that we can now say that the world of appearances is:

a) a series of sense-impressions,

b) a superfluous or gratuitous fact.

In other words, the being of appearances, the transphenomenality of phenomena, simply means that the world of appearances, the phenomenal world, understood both (depending on the level at which Sartre 
is playing his conceptual game) as the world of sense-impressions and as the world "conceived" independently of consciousness, is superfluous or gratuitous. But the "gratuitousness" of the world simply means the belief that there is no ultimate meaning to existence. And what Sartre is actually doing is transforming this personal conviction into a name, "transphenomenality," which is then viewed by him as a constitutive element of the world of appearances. And if this isn't a category mistake, then I don't know what is.

Let me just say a few words regarding your comments on my paper on existence. It was, as a matter of fact, written against certain neothomist, existentialist and "linguistic" interpretations of existence, and I really don't think it is "very close" to Sartre's conception except in the sense of dealing with the same type of problem. I don't really know what you are referring to when you say that "the paradox in your analysis finds its parallel in Sartre." It seems to me that Sartre perpetrates his category-mistake in order to avoid the paradox. I agree, to a large extent, with your characterisation of the paper, though I certainly would not wish to call it "phenomenalism." This is clearly one of the main points where you and I differ. "Phenomenalism" means, surely, that we start off with the idea of experience as something essentially private, whereas my whole tendency is to say, on the contrary, that a great deal of experience is, in some sense, a participation in existence. The problem is, then, to know what elements of experience this would apply to, and in what sense. That is why it seems to me that the notion of a phenomenon is very badly in need of analysis. One way round the difficulty would be the direction Strawson takes: you describe the main characteristics of the world of appearances and call that your "ontology." But I think that this is a misuse of the word "ontology," since it now refers only to the world of appearances without specifying what limits one sets to the very idea of a world of appearances.

I hope that the above answers at least some of your queries. But it does not answer the most important point you raise: "Are you saved from the phenomenalism only by your assertion that the pen exists independently of you? That is an assertion, is it not, and not a predication?" And you then assimilate this assertion to that of Sartre regarding "gratuitousness": "By the same token, to say objects exist . . . is to reveal a personal conviction. Or do you want to say that we experience the existence of objects?" To this, I would like to say just two things:

I) I would certainly not say that we "experience" the existence of objects, but I would say that we know that a great deal of what we experience is not merely subjective or private. As Moore would say, 
I know perfectly well that my hands exist ... It is precisely this knowledge which has to be clarified, and it is precisely for this reason that "what this chair in front of me is," and "that this chair exists" are not two separate parts of the chair, but two distinct starting-points for attempting to understand "this chair" ("this world"). The overemphasis on the first has led, in my opinion, to the over-emphasis on science and the decline of philosophy. [And let me add that, in my opinion, the distinction between the what and the that of "this chair" is precisely what is missing in Sartre: it is not the distinction between the "pour-soi" and the "en-soi"; it is a distinction in that area within which Sartre simply bundles, without any clarification whatsoever, the existing world as "appearance" (and a series of sense-impressions), and the existing world as a fact independent of you and me. His use of the concepts "en-soi" and "pour-soi" cuts across both these aspects because his aim is not to clarify the concept of existence, but to assert that it is gratuitous].

2) To asscrt that things exist and to assert that the totality of existing things is gratuitous are two totally different types of assertion. The assertion that things exist is an assertion which we know to be true: what we don't know is exactly what such an assertion entails. I therefore entirely disagree with you when you say that the assertion of existence is as much of a "personal conviction" as the assertion of gratuitousness. Moreover, I believe that you were not really convinced by your own assertion since you qualify it by saying "in your sense of exist." But what I start off with is not any particular sense of "exist": it's what we both understand perfectly well when I say "there is (or exists) a building in Toronto called Trinity College." What would be "my sense" of "exist" is what I hold, after analysis, to be implied by the fact of existing things. And this, of course, is a theory-a theory which is justified or unjustified according to the value of the analysis. Any philosopher who denies or virtually denies existence (e.g. by holding that everything is reducible to sense-impressions) denies his own assertion by his everyday life: one doesn't eat sense-impressions for breakfast, one eats eggs and bacon. But all this is surely generally agreed on isn't it?

To assert that the totality of existing things is gratuitous is not to assert something which we know to be true. It's a theory, a hypothesis, and in Sartre's case a purely arbitrary and a priori one since he nowhere justifies it. In fact, far from justifying it, it is the arbitrary foundation stone of his whole literary construction.

One last point. I think that part of the reason for your holding that my attempted start at a solution of the problem of existence is akin 
to that of Sartre is that I see the problem in the same sort of way as the existentialists do as opposed to the philosophers of logic (e.g. Frege). To that extent, I would certainly agree with you. I certainly don't think that the problem of existence is reducible to the problem of the quantification of concepts or, as Quine has put it, of knowing what sorts of things there are. This, in my opinion is simply to miss the problem of existence. But $I$ think it only fair to add that the greatest of these "logical" philosophers, namely Wittgenstein, was perfectly well aware of the real problem of existence: "that the world exists is the mystical." The fact that on his own principles he was forced to regard the problem itself as illicit does not, in my opinion, detract from his insight: it simply adds a further reason, and a weighty one, for putting into question, as Wittgenstein himself did later, the principles of the Tractatus. Let me put it this way: if the existentialists and para-existentialists had a modicum of the rigour in thinking which the philosophers of logic have, then there might have been, on their part, such a thing as a philosophy of existence.

A. S.

7. ., May $7 / 67$.

Your last letter clarifies much of our discussion, though I think it still misses one or two points in my attempts at formulating and making sense of the metaphysical and epistemological problem Sartre was presenting. You are certainly correct in saying that "if the existentialists and para-existentialists had a modicum of the rigour in thinking which the philosophers of logic have, then there might have been, on their part, such a thing as a philosophy of existence." What is so important in your "Exister" article (and in a negative way in your critique of Sartre in your Dialogue article) is that you have given a clear and penetrating sketch of a philosophy of existence. My own feeling is that your analysis of existence has a metaphysical (or ontological) bias; that is no sin for me since I think biases are inescapable in metaphysics, even necessary. As a final comment, let me make the following points about your last letter.

(1) You accuse Sartre of playing on two levels. I have been trying to suggest that such two-level operation is characteristic of metaphysics in general. The two levels lead, in the case of phenomenalism, to paradox. The phenomenalist wants to say that all there is is awareness and its contents, while at the same time wanting to find a way of saying awareness and its contents exist: what is is dependent upon awareness but the complex of awareness and its contents also exists. It may well be 
that in the end the phenomenalist cannot really say both of these things, that his language has no vocabulary in it which will permit him to talk of existence apart from the language of experience. The language of experience is our only language but we sometimes find the need to use that language in order to make transcendent claims. Those transcendent claims are not about a thing in itself, a world other than our world: they are claims about the fact of our world as an existent. You make this point nicely in your "Exister" article. It is also, I think, what you praise in Wittgenstein when he says: "that the world exists is the mystical." It is mystical in that we cannot say it, all our talk of the world is in terms of qualities and characteristics experienced by us. What Sartre was trying to do, what I think may be done on the reflective thought level, was to find a vocabulary for saying something about the fact that the world exists, even though the only world he recognized was the world as experienced. Phenomenal reality is a series of senseimpressions and something more than a series of sense-impressions. But the something more that it is is not more qualities or characteristics (though of course additional experiences will disclose those); the something more that it is is existent.

(2) You want to say that for Sartre, this additional fact about the world of our experience is the fact of the world's gratuitousness. Being simply there, you say, means, is "synonymous with, being 'superfluous', 'gratuitous'." It does not seem to me that 'being there' or 'exist' is synonymous with 'gratuitous.' In your formulation in your last letter you say that the world of appearances for Sartre is (a) a series of senseimpressions and (b) a superfluous or gratuitous fact. The problem is how we are to express this fact of (b). I would not think we would express this fact-namely, that the world is a gratuitous fact-by saying it is gratuitous. Would we not have to say (a) the world is a fact and (b) it is gratuitous? You say "To assert that things exist and to assert that the totality of existing things is gratuitous are two totally different types of assertion." That is the point I have been trying to make. In short there are three assertions we need to make about Sartre's world: (a) it is a series of sense-impressions, (b) it is, exists, is a fact, and (c) it is gratuitous, contingent, 'de trop.' (Incidentally, (a) is not quite accurate since the world for Sartre also includes awareness. However the totality of that world is to be characterized, (b) and (c) are also true of that world.)

(3) I think the last important difference between us concerns my attempt to say that your own analysis of existence has a bias, embodies a conviction about the nature of the world; that hence on this ground you do not differ from Sartre. You say that you do not start off "with 
... any particular sense of "exist"'. I think you do, but $I$ also know that my claim here is highly debatable. You say that we "both understand perfectly well" what we mean when we say "there is (or exists) a building in Toronto called Trinity College." I do not think it is at all clear what we mean; or, it can mean many different things. I do not think I can separate, as you seem to be able to, a sense of 'exist' prior to analysis and one after analysis. Whether the ordinary person (and you and $I$ in our non-philosophical moments) can be said in any way to have a notion of what it means to say 'there is such and such a building in Toronto', I am not sure. What I do not see is that my acceptance of whatever this fact is, about there being a building in Toronto called 'Trinity College,' implies any particular analysis of the fact that there is such a building. Where the bias enters is precisely through the analysis. Now a bias of another sort-a meta-philosophical bias-appears between us here: I think an analysis of 'existence' can only be given from some general attitudes which are not implied by ordinary assertions or beliefs, you think our ordinary assertions about buildings, etc., themselves give rise to one analysis of "existence." Before you can tell me what it is we understand by saying there is such a building in Toronto, you have to take up some attitude towards existence. Your attitude is realist: the building is there independent of us. Sartre's (and other phenomenalists') attitude is that the building can only be for someone, though the complex of awareness and building exists in some non-phenomenal way. This last claim may not be fully intelligible though its intelligibility may in the end be self-defeating or unsayable. Incidentally, you seem to say in this connection that to hold that everything (save awareness, perhaps) is reducible to sense impressions is to deny existence. That remark shows your bias. I would say that this way of talking about things-as collections of sense impressions -is just one way existence (or a part of existence) can be analyzed. The Dr. Johnson ploy, of saying one does not eat sense-impressions for breakfast but rather eggs and bacon, won't do since Berkeley never denied that one eats eggs and bacon for breakfast. What he said was that what we mean (all that we can mean) by eggs and bacon is a specific congeries of qualities. That was his analysis of existence or of existing things. To say that "things are a congeries of qualities" or to say "things are, exist, but reveal themselves to us via qualities" is to give expression to metaphysical convictions about the nature of the world. We cannot know either to be true or false, just as we cannot know that the world is gratuitous or rational. 